\title{
Improving IT education through leadership development
}

\author{
Mohammed B. Lahkim \\ Zayed University, UAE \\ Gregory J. Skulmoski \\ Zayed University, UAE \\ Russel E. Bruhn \\ University of Arkansas at Little Rock, USA
}

\begin{abstract}
This paper investigates the integration of leadership training into IT curricula to develop current and future skills needed by the IT job market. The technical and non-technical skills required for IT professionals are presented and a conceptual model for including leadership training in technical courses is outlined. To implement this model, we adopted the Problem-Based Learning approach to teach an IT course. Qualitative and quantitative data were gathered, through a survey, from 52 undergraduate students in the College of Information Technology at Zayed University. Our results show that our adopted approach was successful in teaching IT skills as well as developing leadership skills. Given these findings, we highlight the importance and feasibility of integrating leadership development on a daily basis within technical courses to develop both the technical and non technical skills required by the job market.
\end{abstract}

\section{Introduction}

In today's business environment, IT graduates entering the workforce are expected to have strong technical as well as strong leadership skills (Morneau and Talley, 2007). The latter were traditionally learned on the job, but now they are requested at the entry level. Early research on the IT workforce in the 1990's has proven that high technical capabilities, business knowledge, interpersonal skills, and management skills are extremely important (Lee et al., 1995; Tye et al., 1995; Bailey and Stefaniak, 2001). More recent studies and research have demonstrated that the most desirable and lacking skills for current and future entry-level IT workforce are leadership skills besides management skills and business knowledge (Abraham et al. 2006, Zwieg et al. 2006, Benamati and Mahaney 2007). Benamati and Mahaney (2007) argue that "In the past strong technical skills could carry them [IT professionals] until they develop the domain and leadership knowledge. This will be less true over time, as more and more technical work is outsourced". It is a fact that IT professionals who have leadership skills are those most looked for in the job market. Humphrey (2006), who developed the Team Software Process (TSP) at the Software Engineering Institute, Carnegie Mellon University summarizes his experience as follows:

"In the fifty-plus years since I started development work, I have worked on, led, managed, directed, assessed, or coached literally hundreds of creative development teams. While I have drawn many lessons and guidelines from this experience, one clearest message is that leadership makes the 
greatest difference. Without exception, truly creative work is done by teams with capable leaders. [...] What is equally interesting is the converse. When development projects fail, it is almost always because of poor leadership."

In a study by Reich and Nelson (2003), which involved interviewing $50 \mathrm{ClO}$ and IT directors of 22 large organizations in the US and Canada, it was found that the most important skills that were needed for IT professionals were mainly leadership skills including the ability to work effectively in diverse global teams and the ability to negotiate with and influence others. This study has also shown that:

"The gap between the skills needed (negotiation, collaboration, influencing) and the skills normally taught (programming, analysis, decision support) should be a wake-up call for college and university program designers [...]. Special efforts should be made to incorporate some of these elements into undergraduate computer focused programs".

In a university environment, however, faculty members and management are facing many challenges with regard to leadership training. The first and most important challenge is related to the basic definition of leadership. In fact, there are many definitions of leadership, but there is no universal one nor a generally accepted theory of leadership (Goethals and Sorenson, 2006). The real dilemma for academicians, including those in technical fields like IT, is how one could train students on a concept that is still not agreed upon by researchers and practitioners but at the same time is universally acknowledged as very important. Lately, leadership skills are even becoming a major component in accrediting computing programs (ABET, 2008, criterion 3). While it is beyond the scope of this paper to try to define leadership, we limit our discussion to the main skills that IT professionals should develop and that will help them emerge as leaders within their organizations.

The second challenge is the general confusion between management and leadership. In the context of organizations that use IT, management of IT focuses on "how to implement", which includes: project management, change management, resource allocation, and technology acquisition, operation and maintenance. Leadership in IT, on the other hand, deals mostly with organizational direction, strategic use of IT, IT as an enterprise integration enabler, and how IT impacts organizational structure, processes and human resources (Mendonca, 2004). With regard to leadership and organizational direction, Klenke (1993) argues that:

"IS professionals who fail to perform successfully in leadership roles tend to be specialists whose technical expertise has been their sole path to career success at lower levels of management. At higher levels of management this becomes a weakness because exclusive focus on technical expertise interferes with attention to the interpersonal and conceptual competencies necessary for effective leadership[...]. This means that IS professionals who seek leadership roles in an information dominated society must develop skills and competencies beyond technical and managerial expertise. They must be able to change things beyond technologies by making substantive differences in organizations".

The third major challenge, based on our experience in IT colleges, is that there is little room for adjusting IT curricula and providing a course or two on leadership. Therefore, this research presents a potential alternative by integrating leadership development within technical courses.

The overall objective of this research is to investigate how to incorporate leadership development within an existing IT course. If successful, it will allow the development of both technical and non-technical skills required for the IT job market. More specifically, the following research objectives are targeted:

i) Identify the main leadership skills that need to be developed by IT students to comply with the needs of the IT job market both globally and locally, 
ii) Test a skills-based leadership model for including leadership development in technical courses, based on the following four dimensions:

a) technical skills,

b) interpersonal skills (e.g. teamwork and communication),

c) conceptual skills (e.g. problem solving and independent learning), and

d) management skills (e.g. planning and time management).

iii) Test the Problem-Based Learning (PBL) approach to implement the suggested conceptual leadership model in an IT course. Although PBL is known as an educational tool, it has emerged lately as a promising leadership development approach given the changing roles required of leaders in a fast changing global economy (Bridges and Hallinger, 1996; O'Connor, 2004; Yeo, 2007). Recently, PBL has proven to be very effective in teaching time management, planning, negotiation, collaboration, research skills, interdependence, identification and capitalization of individual skills, communication, problem solving and teamwork (Herron and Major, 2004).

Note that in practice there is no generally accepted understanding of or distinction between Information Technology (IT) and Information Systems (IS). These two terms will therefore be used interchangeably in this paper.

\section{Current and future skills required for IT professionals}

Much of the research in IS in the last several decades has focused on identifying the technical skills required for improving the performance of IS professionals (Bassellier et al., 2001). For example, the required software development skills are detailed in The Guide to the Software Engineering Body of Knowledge (Abran et al., 2004). The knowledge and skill requirements have been reviewed from 1970 to 1990 for programmers, systems analysts and IS managers (Todd et al., 1995). The skill and knowledge requirements of systems analysts have also been studied (Lee et al., 1995; Nord \& Nord, 1995), crosscultural comparisons have been established (Hunter \& Beck, 1996), and their relationship with the maturity of the organization has been explored (Benbasat et al., 1980).

Non-technical skills of IS staff, such as business process reengineering (Im et al., 1999), and trustworthiness and credibility (Bashein \& Markus, 1997) are other areas of research interest and are key components of leadership skills. The perceptions of systems analysts skills and project failure have also been investigated (Klein et al., 1999). Research has also been completed on the perceptions, preferences, age and gender of systems analysts (Lerouge et al., 2005). The most important behavioral skills of IS project managers were shown to be interviewing, directing and managing (Jiang \& Klein, 1998). Systems analysts orientation to work (user-oriented, technically-oriented, and politicallyoriented) and their perceived skills have also been studied (Jiang et al., 1999). The skills necessary for successful outsourced software development projects is another competency research area (Seppanen, 2002). Understanding and measuring end user competence in information systems has been an enduring stream of research efforts (Igbaria \& livari, 1995; Igbaria et al., 1999; Marcolin et al., 2000; Marcolin et al., 1997; Munro et al., 1997).

Beaumont and Frank (2003) showed that problem solving, teamwork, innovation, business awareness, confidence and reflection are the most required skills in the IT job market. In a more recent study, Morneau and Talley (2007) argue that given the global economy changes, traditional hard skills (like programming) are becoming cheap commodities that can be afforded easily through outsourcing; while the emerging skills required in the market nowadays are: architecture skills (which consist of creatively planning and designing enterprise wide business systems), leadership/followership, communication, 
collaboration, problem solving, critical thinking, creativity, innovation, global business expertise, systems thinking, and self management.

Skulmoski and Hartman (2009) found that to contribute to IS projects, all team members, including the project manager, require at least threshold competencies to be considered minimally competent (Figure 1). Without these threshold competencies, the project team member will struggle to contribute to the IT project. Many of these threshold competencies are leadership skills that can be developed through training (e.g. problem solving, verbal communication and basic project management skills such as estimating task durations). However, some of these threshold competencies are leadership traits (e.g. confidence) and motives (e.g. professionalism) that are more difficult to develop. None the less, they need to be present in and applied by people in projects.

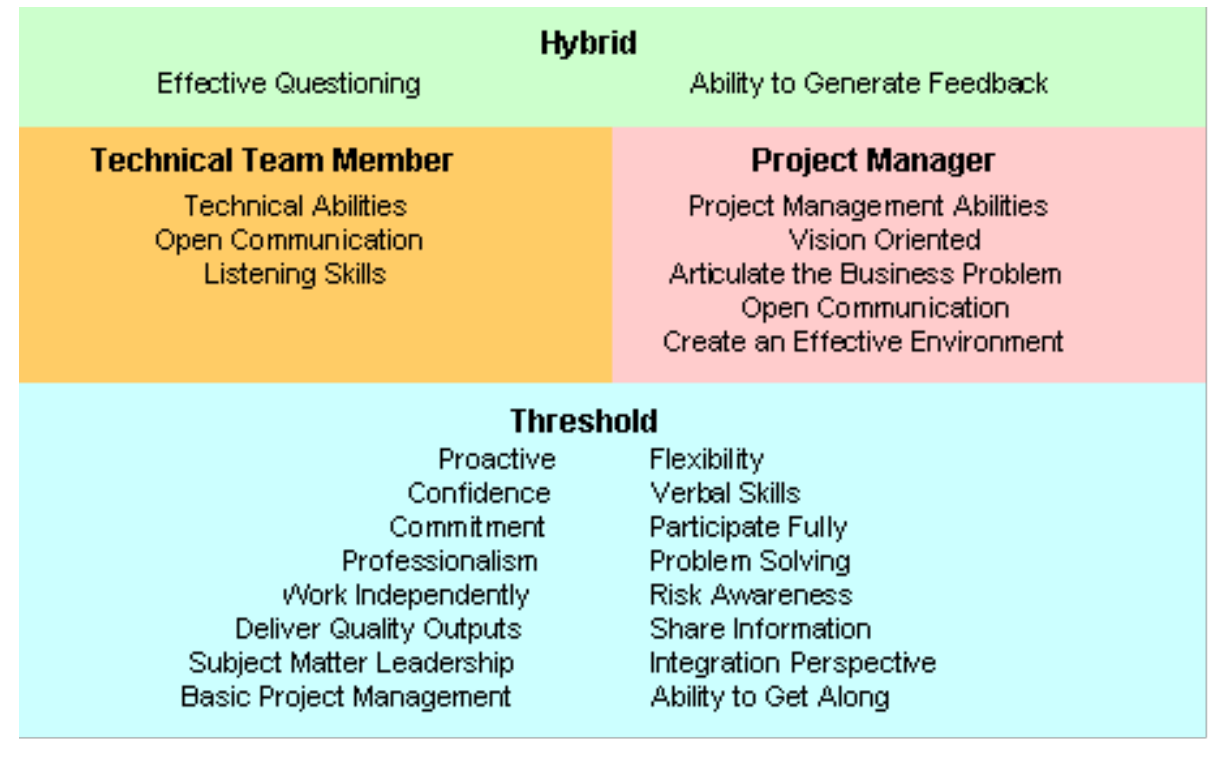

Figure 1: Project management competence configuration (Skulmoski \& Hartman, 2009).

Technical people do require both technical and soft skills, including the threshold skills mentioned above, to be successful (Skulmoski and Hartman, 2009). The technical position is not only about technical work; it is working with others to plan, organize and implement technical plans. To work effectively with others, technical team members need soft skills such as the ability to listen and communicate openly.

The project manager's focus is more on planning, managing and controlling, rather than on technical details of the IS project (Skulmoski and Hartman, 2009). While they do not need to be technically superior, project managers need both to understand the basic elements of information technologies and to delegate technical responsibilities to other members of the team (e.g. technical team and hybrid members). Therefore, their required competencies begin with solid project management competencies. They also require leadership competencies such as articulating the business problem, then developing and advancing the project's vision; and these require open communications. They also have to create an effective environment for the team. The project manager needs the threshold competencies in addition to these competencies. 
The hybrid team members require both technical and managerial competencies, in addition to the threshold competencies for project success (Skulmoski and Hartman, 2009). They are the supervisory go-between for the technical team and the project manager. They are delegated the responsibility to ensure the technical deliverables are completed. To fulfill these responsibilities, they need most of the competencies of both the project manager and the technical team but not to the depth of expertise of either. However, hybrid team members usually come from the ranks of the technical team and slowly are given more supervisory and project management responsibilities. They often develop project management and supervisory skills on an ad hoc basis with very little formal training. Thus, as the IT person's role changes and there is a progression towards project management, the required competencies for success also change. All IT project participants, not only the project manager, require some leadership skills. The key skills and competencies related to leadership for technical team members are shown in Table 1.

\begin{tabular}{|l|l|}
\hline Author(s) & Technical Team Member Skills/Competencies \\
\hline Lee et al. (1995) & Technical skills within their discipline \\
\hline Jiang et al. (1999) & User-oriented, technically-oriented, politically-oriented \\
\hline Bassellier et al. (2001) & Technical skills within their discipline \\
\hline Beaumont and Frank (2003) & $\begin{array}{l}\text { Problem solving, teamwork, innovation, business awareness, } \\
\text { confidence and reflection }\end{array}$ \\
\hline Morneau and Talley (2007) & $\begin{array}{l}\text { Leadership/followship, communication, collaboration, problem } \\
\text { solving, critical thinking, creativity, innovation, global business } \\
\text { expertise, systems thinking, and self- management }\end{array}$ \\
\hline Skulmoski and Hartman (2009) & $\begin{array}{l}\text { Proactive, confidence, commitment, professionalism, work } \\
\text { independently, deliver quality outputs, subject matter } \\
\text { leadership, basic project management, flexibility, verbal } \\
\text { communication, participate fully, problem solving, risk } \\
\text { awareness, share information, integration perspective, and } \\
\text { ability to get along }\end{array}$ \\
\hline
\end{tabular}

Table 1: Technical team member skills.

In response to the needs of the IT job market in terms of IT professionals with technical and non-technical leadership skills, new accreditation criteria are set by the Accreditation Board for Engineering and Technology (ABET). Almost half of them involve leadership skills that need to be developed at the university. Plans are being made for the College of Information Technology at Zayed University to become ABET accredited. The latest 2008-2009 ABET criteria for accrediting computing programs specify that students should be able to achieve the following outcomes by the time of graduation (ABET 2008, criterion 3: program outcomes); and the outcomes can be divided into two categories:

Technical outcomes:

- An ability to apply knowledge of computing and mathematics appropriate to the discipline.

- An ability to analyze a problem, and identify and define the computing requirements appropriate to its solution. 
- An ability to design, implement, and evaluate a computer-based system, process, component or program to meet desired needs.

- An ability to use current techniques, skills, and tools necessary for computing practice.

- An ability to use and apply current technical concepts and practices in the core information technologies.

- An ability to identify and analyze user needs and take them into account in the selection, creation, evaluation and administration of computer-based systems.

- An ability to effectively integrate IT-based solutions into the user environment.

\section{Non-technical outcomes (directly or indirectly related to leadership)}

- Recognition of the need for and an ability to engage in continuing professional development.

- An ability to function effectively in teams to accomplish a common goal.

- An understanding of professional, ethical, legal, security and social issues and responsibilities.

- An ability to communicate effectively with a range of audiences.

- An ability to analyze the local and global impact of computing on individuals, organizations and society.

- An understanding of best practices and standards and their application.

- An ability to assist in the creation of an effective project plan.

Of the 14 program outcomes, seven are technical, while the other seven (50\%) are non technical and relate directly or indirectly to leadership. This would require training in teamwork, visioning, motivating, being aware of the ethical dimensions of IT practice, planning, and communicating effectively. ABET criteria not only require programs to show the quality of their courses but also to show documentation that graduates are able to achieve the technical as well as non-technical (leadership) skills. The latter are expected to be developed within the context of technical courses. It is also the responsibility of all faculty members to: i) work on the technical outcomes as well as the non-technical ones in their courses and ii) assess the learning outcomes for the purpose of ABET accreditation. The challenge for faculty members is how to achieve these outcomes given that ABET does not provide specific guidelines. One of the contributions of this paper is to suggest a method for implementing and assessing these outcomes.

The ABET criteria are universal and therefore apply to IT professionals in the Gulf. All the technical and non-technical outcomes should help IT professionals regardless of where they are located. These outcomes are also consistent with the findings of the GLOBE studies on culture and leadership, which provide the strongest body of findings, to date, on culture and leadership. These studies confirmed that interpersonal skills, including those listed by ABET, are universally endorsed by all cultures (House et al., 2004).

\section{Problem based learning for IT education}

Some of the early studies to fill the gap between what the IT job market needs in terms of skills of IT professionals and what the university is offering as training have suggested radical solutions by introducing a multidisciplinary curriculum in information sciences called informatics: a field that combines computer science, business, and behavioral sciences (Trauth and Hafner, 2000; Kay et al., 2005). Our approach in this research is different. We tested using the Problem-Based Learning (PBL) approach to develop both leadership and technical skills without changing the curriculum. In PBL the learners work in teams on real world problems, which represent the incentive for learning, before they receive the information and knowledge necessary to solve it (Major, 1999, 2001; Schmidt and Moust, 2000). In PBL, working on the problem is not testing students' skills, but it is developing their skills. "The 
principal idea behind problem-based learning is that the starting point for learning should be a problem, a query or a puzzle that the learner wishes to solve... Problem based courses use stimulus material to engage students in considering a problem which, as far as possible, is presented in the same context as they would find it in 'real life'. This often means that it crosses traditional disciplinary boundaries. Information on how to tackle the problem is not given, although resources are available to assist the students to clarify what the 'problem' consists of and how they might deal with it" (Boud and Feletti, 1997). It is noteworthy that PBL is different from a Project Based Learning approach. In PBL, the problem to be solved is introduced before the students know how to solve it, as it becomes the trigger for learning. In the project based approach, on the other hand, students use what they have learned earlier to solve a new problem generally towards the end of the course. Learning activities are pre-defined and organized around achieving a common project with clear procedures and steps to be followed (Savery, 2006).

Historically, PBL has proven to be very effective in many fields. It was developed in the medical education field in the early 1970's (Barrows 1985, 1986, 1992), and has since been adopted in many other areas including business, education, architecture, law, and social sciences. Lately, it started being used in engineering (Prince, 2004; Kumar and HSIAO, 2007). Ellis et al. (1998) argued that PBL is well suited for the computing discipline because:

1. Computing is for the most part problem driven.

2. Lifelong learning is a necessity due to the rapidly and continually changing nature of the IT industry.

3. Practitioners must constantly update their skills and competencies in order to keep abreast of new technology.

4. The project group is the predominant mode of operation within the industry.

5. Computing crosses discipline boundaries.

With all these advantages, however, PBL is not widely used in the IT field (Beaumont et al., 2004). This is mainly due to the extensive faculty training, professional development and management involvement that it requires:

"The greatest barrier to PBL may be political. Adoption of a PBL curriculum necessitates a radical change in faculty and administrative attitudes. Faculty must become more exposed to students, departments must relinquish some curricular authority, curriculum matters must assume a more important status. Such changes are not easy in an established, conventional school" (Donner and Bickley, 1993).

In the last decade, PBL has been used (mostly in programming) as presented in Table 2. From this list we may deduce that PBL has not been widely used across the whole curriculum. Recent research is underway and is still needed for making the switch from traditional curricula to new PBL based ones (Astrachan, 2008).

\begin{tabular}{|l|l|}
\hline Course & Reference \\
\hline Computer science course for engineering & Lambrix and Kambar (1998) \\
\hline Programming course & $\begin{array}{l}\text { Greening et al. (1997); Ellis et al. (1998); Fekete } \\
\text { \& Greening (1998); Kay \& Kummerfeld (1998); } \\
\text { Hadjerrouit, S. (1999); Barg et al. (2000); Duke }\end{array}$ \\
\hline
\end{tabular}

Lahkim, M., Skulmoski, G.J. \& Bruhn, R.E. (2009). Improving IT education through leadership development. Learning and teaching in higher education: Gulf perspectives, 6(1). http://www.zu.ac.ae/lthe/Ithe06_01_03_lahkim 


\begin{tabular}{|l|l|}
\hline & $\begin{array}{l}\text { et al. (2000); Kay et al. (2000); Adams et al. } \\
\text { (2001); Pollock \& Jochen (2001); Clarke et al. } \\
\text { (2005); Nuutila et al. (2005), O'Kelly and Gibson } \\
\text { (2006). }\end{array}$ \\
\hline Software engineering & $\begin{array}{l}\text { McCracken and Waters (1999); Oriogun and } \\
\text { Georgiadou (2000); O'Kelly et al. (2005). }\end{array}$ \\
\hline Systems analysis and design & Bentley (2002, 2005). \\
\hline Senior project course & Uden (2003). \\
\hline Networking/security & Beaumont and Frank (2003). \\
\hline Theoretical foundations for computer science & Hämäläinen (2004). \\
\hline $\begin{array}{l}\text { Introduction to computer organization and } \\
\text { architecture }\end{array}$ & Garcia-Famoso (2005). \\
\hline Computer graphics & Davis et al. (2004); Marti et al. (2006). \\
\hline
\end{tabular}

Table 2: Use of PBL in IT courses.

In terms of assessment of PBL courses, new techniques have been developed that are consistent with the PBL philosophy, although, in practice, faculty using PBL partially use some of the traditional testing methods (Boud and Feletti, 1997; Waters and McCracken, 1997; Ellis et al., 1998; Segers et al., 1999; McCracken and Waters, 1999; Yip and Ghafarian, 2000; Duch et al., 2001; Segers and Dochy, 2001; Hämäläinen, 2004; Uden and Beaumont, 2006).

\section{Skills-based leadership model}

Leadership development is a lengthy and very complex process, that needs to be worked on on a day to day basis and for a long period of time. It must be developed during the whole academic and professional life. In this paper, we suggest adopting a long term approach where leadership training is introduced in technical courses and not as one single course devoted to leadership. For the purposes of this paper, we discuss the implementation in only one course, but the approach could be generalized to other IT courses.

The theoretical framework for this study is based on the leadership skills approach which addresses leadership as a set of developable capabilities (skills and knowledge) that can be learned and developed over time through education and experience, as opposed to personal characteristics that are considered innate (Mumford et al., 2000, Yammarino, 2000). This approach presents leadership development within an organizational context, which is consistent with many curricula of leadership education. A skill can be defined as "an ability which can be developed, not necessarily inborn, and which is manifested in performance, not merely potential" (Katz, 1955, p. 33-34). Examples of skills that are developed by a leader in an organization include: technical skills in a specialized area, human or interpersonal skills, and conceptual skills like visioning, strategic planning, and understanding the enterprise social, economical and ethical context. According to this approach, if people are capable of learning from their experience or through their education, they then eventually develop as effective leaders and their effectiveness can be measured in terms of their ability to solve complex organizational problems (Mumford et al., 2000b).

The leadership skills model has five major components, namely: individual attributes, leadership competencies, leadership outcomes, career experiences and environmental influences (Mumford et al., 
2000a, Yammarino, 2000). To these components, we add a sixth one introduced by Mumford et al. (2007) to include business and management skills. These components are described as follows:

1. Individual attributes (conceptual skills) include intelligence, creativity, openness, visioning, tolerance for ambiguity, curiosity, information processing abilities, general reasoning skills, problem solving skills, critical thinking, prioritizing, motivation, awareness and adaptation to the professional, ethical, legal, and social context, and willingness to take responsibility and risk to solve organizational problems.

2. Leadership competencies include interpersonal skills like communication with others, understanding others unique needs and motivations, working with others even in case of resistance and conflict, collaborating, negotiating, and developing a teamwork attitude to work. Leadership competencies also include the knowledge and expertise developed by the leader in his/her area of specialty.

3. Leadership outcomes include effective problem solving within the organization and the degree to which the individual has performed his duties (performance) as measured by his superiors.

4. Career experiences include the training and mentoring that the leader develops at work.

5. Environmental influences include the outside environmental factors that influence the leaders performance at work.

6. Business and management skills include the management and business training that the leader gets at work or through his/her education. Examples include coordination, resource allocation, time management, scheduling, reporting, and task distribution.

Given that in our context research leadership development is primarily in the classroom, components of leadership outcomes, career experience, and environmental influences that mainly develop at work are not being considered here, since they are beyond the scope of classroom training. Therefore, our model for leadership development in the classroom as represented in Figure 2 includes four dimensions or sets of skills to be developed:

1. Technical skills or knowledge developed through technical courses, capstone projects and internship.

2. Conceptual skills.

3. Interpersonal skills.

4. Business/ Management skills.

All four dimensions in Figure 2 are interrelated. For example, the problem solving skills (conceptual skills) of a leader would allow him/her to come up with new solutions, that can only be implemented through effective communication and collaboration with other team members. A successful implementation of the solution also requires good resources management and a good business strategy. This reflects better real world complexities and situations as well as a natural integration of skills learned by students on a day to day basis throughout the curriculum. 


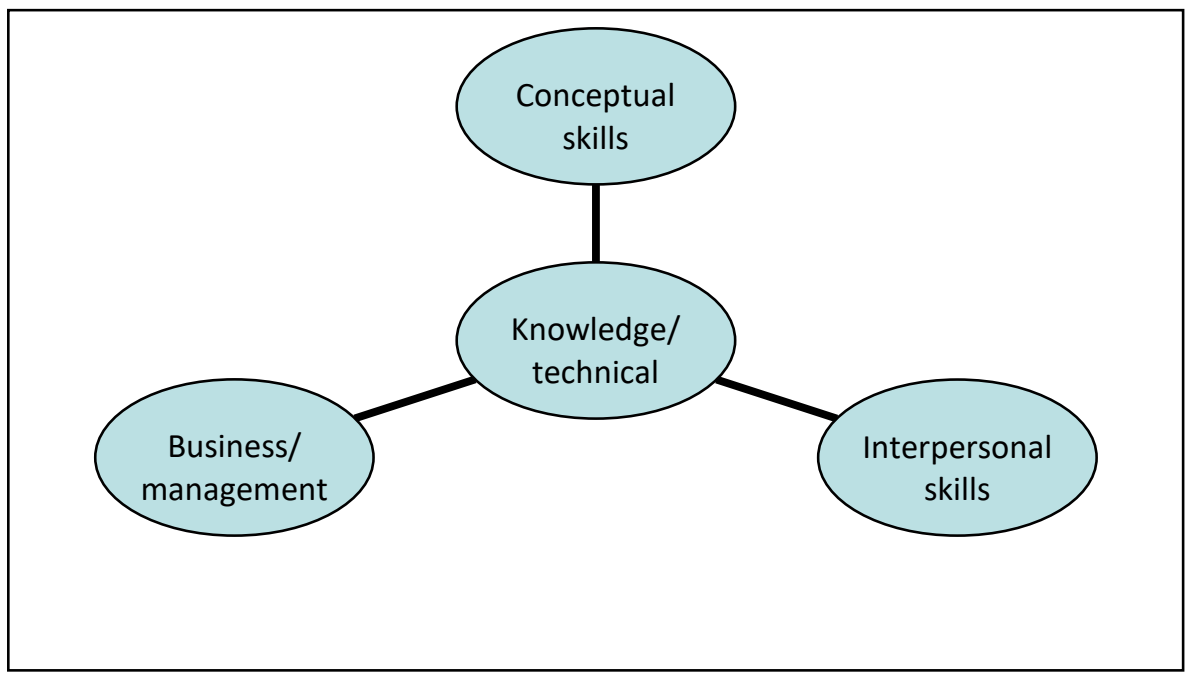

Figure 2: Conceptual model for leadership training in an IT course.

In Table 3 below, these four leadership dimensions (sets of skills) are matched with the leadership skills requested by the IT job market, the latest $A B E T$ accreditation requirements, and what the PBL approach could develop within the context of IT education:

\begin{tabular}{|c|c|c|c|}
\hline $\begin{array}{l}\text { Leadership } \\
\text { dimensions }\end{array}$ & Required Leadership skills [1] & $\begin{array}{c}\text { ABET (2008) } \\
\text { Criterion } 3\end{array}$ & $\begin{array}{l}\text { Developed } \\
\text { by PBL [2] }\end{array}$ \\
\hline $\begin{array}{l}\text { Conceptual } \\
\text { skills }\end{array}$ & $\begin{array}{l}\text { - Visioning. } \\
\text { - } \text { Adaptation to change \&determination. } \\
\text { - } \text { Confidence and reflection. } \\
\text { - } \text { Problem solving. } \\
\text { - } \text { Independent lifelong learning. } \\
\text { - Awareness of the professional, ethical, legal, } \\
\text { and social environment }\end{array}$ & $\begin{array}{l}\mathrm{v} \\
\mathrm{v} \\
\mathrm{v}\end{array}$ & $\begin{array}{l}v \\
v \\
v\end{array}$ \\
\hline $\begin{array}{l}\text { Management/ } \\
\text { Business skills }\end{array}$ & $\begin{array}{l}\text { - } \quad \text { Planning. } \\
\text { - } \quad \text { Time management. } \\
\text { - } \quad \text { Project management. } \\
\end{array}$ & $\mathrm{V}$ & $\begin{array}{l}v \\
v \\
v\end{array}$ \\
\hline $\begin{array}{l}\text { Interpersonal } \\
\text { Skills }\end{array}$ & $\begin{array}{l}\text { - } \quad \text { Communication (verbal and written). } \\
\text { - } \quad \text { Teamwork, cooperation and collaboration. } \\
\text { - Influencing others. }\end{array}$ & $\begin{array}{l}\mathrm{v} \\
\mathrm{v} \\
\mathrm{v}\end{array}$ & $\begin{array}{l}v \\
v\end{array}$ \\
\hline $\begin{array}{l}\text { Technical } \\
\text { Skills }\end{array}$ & $\begin{array}{l}\text { - IT construction skills (e.g. programming, } \\
\text { Databases). } \\
\text { IT architecture skills (Morneau and Talley, } \\
\text { 2007). }\end{array}$ & $\mathrm{v}$ & $\begin{array}{l}\text { (References } \\
\text { presented } \\
\text { in Table 2) }\end{array}$ \\
\hline
\end{tabular}

Table 3: Development of Leadership skills matched to job requirements, ABET accreditation criteria, and PBL outcomes.

[1] cited in (Beaumont and Frank, 2003), unless mentioned otherwise 
[2] cited in (Herron and Major, 2004), unless mentioned otherwise

\section{Developing leadership within IT courses}

In order to test the skills-based leadership model presented in Section 4, the PBL teaching approach has been adopted to teach an IT web course in the College of Information Technology at Zayed University, United Arab Emirates (UAE). Adopting PBL has a dual benefit of teaching a web technology course and developing leadership skills for IT students. The following section presents a description of: (i) the academic environment where this course is implemented, (ii) the course and how it was implemented, (iii) how the assessment was performed and (iv) a summary of results and discussions.

\section{Academic environment}

In the last few decades, leadership has become one of the most consistently advocated outcomes in higher education. Zayed University, for example, where this research is being conducted, has a vision to prepare graduates to become leaders in government, business, civil society, and family life. The University expects its graduates to be fully bilingual in English and Arabic, proficient in the use of computing technology, and strong in quantitative and research skills. The language of business and instruction at the university is English. The University has about 600 faculty and staff, 3500 students across two campuses in Dubai and Abu Dhabi. It is fully accredited in the U.A.E, and it was internationally accredited by the Middle States Commission on Higher Education in July 2008.

The University has set up a leadership institute that provides a forum in which students develop their leadership skills. The goals of this institute are to:

1. Make Zayed University a local and regional model for distinctive leadership education.

2. Ensure students graduate with a foundational level of leadership knowledge and experience.

3. Educate the entire individual for service through leadership.

4. Offer opportunities for advanced leadership knowledge and skill development.

5. Engage students with the community through volunteerism and community-based problem solving that emphasize a values-centred leadership.

Leadership development for students is done through events spread over the academic year and organized as workshops and lectures. While the existence of such leadership training program is very important, we believe that it will not be sufficient and fully effective unless leadership development is implemented in the classroom on a daily basis. For this purpose, we have redesigned the curriculum of an introductory web development course (CIT 245). It had been previously taught using the traditional lecturing approach of following a good textbook, doing exercises, homework and testing. This method has always been efficient in teaching the necessary technical skills to students (one dimensional approach), but it does not necessarily develop other non-technical skills.

\section{Course description and implementation}

After being redesigned using the conceptual model in Figure 2, the course learning outcomes became as follows:

1. Learn web development concepts and techniques.

2. Develop a vision of a large technical project and define its goals. 
3. Develop interpersonal skills (communicate orally and in writing, be a team player within interdisciplinary teams, motivate, and convince team members about the use of their project for their society).

4. Develop management skills (e.g.: time management, planning, task distribution and scheduling) to implement the project.

In the first two weeks of the semester, students are introduced to the course and its outcomes, and to the problem based learning approach and how different it is from the traditional lecturing approach. They are asked to define a problem of their choice, for which a solution will be developed through a technical project. All the learning activities throughout the semester are in relation to this project. Rather than simplifying the problem for students, the instructor encourages them to chose a real world one to reflect reality. Students are also coached on how to develop a vision for their project, how to plan a project and how to write their project proposal and report. Around 30 students every semester are divided into groups of 3 to 4 team members from different backgrounds. Each team chooses a team or project leader who has a major coordination role. It is very fortunate that students taking this course are from various colleges at ZU: IT, Business, Education, and Arts and Sciences. This trains students to work efficiently within interdisciplinary teams, and to learn from each other different skills. As for the choice of the topic, students are encouraged to make their own choice providing that it stays within the context of web development. Subjects with content that crosses boundaries between disciplines are encouraged. Examples of web sites developed in the last two semesters include:

- A web site about Arabic coffee history, types and how it is prepared and served according to traditional customs and traditions.

- A web site that would help a newly married couple prepare for their wedding day and make good choices about their wedding supplements.

- A web site about people with special needs, e.g. Down syndrome, autism, and dyslexia.

During the rest of the semester, the instructor adopts a coaching and consulting role. He provides students with tutorials on topics directly related to the development of the project. Students are not asked to study and memorize technology from a textbook, but rather to use the technology for implementing their projects. Examples of tutorials include: how to develop and design a basic web page, how to design a web site with tables, frames and forms, and how to use multi-media on the web. Students are also encouraged to use all the resources available in the library and internet and any other media to support their learning experience.

The instructor does not dictate how the student should develop the implementation of their project, what to do and how to think, but rather encourages them to explore different options and alternatives. Questions like "Why?", "What would be the impact of publishing your web site?", "Is there anything else that could be done to make it better?", "Why would people be interested in your web site?" trigger a critical thinking process. The instructor also provides very clear guidelines on what needs to be delivered. Students are challenged in every step of their progress on why and how they could improve their work. To avoid social loafing, where students cease being active and rely on others, every team leader is asked to provide, as part of the project proposal, a task distribution list and timetable to be followed by each team member. The instructor follows up with student's progress in each session and checks on the quality of the task being done. Self and peer evaluation is also introduced for the same purpose. At the end of the semester, students are asked to reflect on their learning of web technologies, as well as the challenges they faced. All project developments and finding are then summarized in a report followed by a presentation. 


\section{Assessment}

Most of the assessment is done around the project either directly or indirectly. Two traditional tests are given on web development and design issues, as all students have faced them while doing their project (they are worth $30 \%$ of the course). Many tutorials are given to students to support their learning while doing the project ( $10 \%$ of the course). The rest of the assessment is directly related to the project and is outlined as follows:

\begin{tabular}{|c|c|}
\hline Component & Items * \\
\hline Project report & $\begin{array}{l}\text { - } \text { Project vision, goals, content description. } \\
\text { - } \text { Analysis of its impact on individuals, organizations or the society. } \\
\text { - } \quad \text { Distribution of responsibilities among team members. } \\
\text { - } \quad \text { Timetable (weekly or even daily) of project steps to be completed by } \\
\text { specific dates for each team member. } \\
\text { - } \quad \text { ist of the technologies used, whether they were learned in class or } \\
\text { outside the classroom. } \\
\text { - } \text { Bibliography containing references to any books, magazines, web sites } \\
\text { - } \text { where the information is extracted. } \\
\text { technical details that the reader would like to refer to. }\end{array}$ \\
\hline $\begin{array}{l}\text { Project } \\
\text { implementation }\end{array}$ & $\begin{array}{l}\text { - The web site should be attractive, informative, interactive, easy to use } \\
\text { in a reasonable load time, well targeted towards a specific audience, and } \\
\text { portable to many web browsers. }\end{array}$ \\
\hline Presentation & $\begin{array}{l}\text { - Content, interaction with the audience, fluency, delivery and ability to } \\
\text { answer questions. }\end{array}$ \\
\hline Teamwork & $\begin{array}{l}\text { - Fairness of workload, leadership role and contribution of each team } \\
\text { member, besides peer and self evaluation using published criteria (Ulden } \\
\text { and Beaumont, 2006). }\end{array}$ \\
\hline $\begin{array}{l}\text { Creativity and } \\
\text { independent } \\
\text { learning }\end{array}$ & $\begin{array}{l}\text { - Choice of topic, content, learning processes, and creativity in learning } \\
\text { new materials and implementing them in the project. }\end{array}$ \\
\hline
\end{tabular}

Table 4: Project components and assessment.

(*) While working on the project, students are given clear and detailed guidelines and well specified deadlines on what needs to be delivered, and how each criteria is evaluated.

\section{Results and discussion}

At the end of the Fall and Spring semester of the 2007/2008 academic year, a questionnaire was distributed to 62 students by the Assistant Dean of the College of Information Technology. 52 students provided their feedback and their answers are summarized in Appendix A. The questionnaire was divided into four major skill areas which are the focus of this research and are adopted from the 
leadership skills approach: i) knowledge/ technical skills, ii) human/interpersonal skills, iii) conceptual skills, iv) and business/ management skills. Statistics in Appendix A regarding the development of these skills show that about $90 \%$ of students either agree or strongly agree that the adopted teaching method improved their:

1) Conceptual skills in terms of becoming:

a. A better leader/ follower.

b. A more independent learner.

c. More creative.

d. More confident about their abilities.

e. Better at problem solving.

2) Management skills like time management and project planning

3) Interpersonal skills in terms of becoming:

a. A better team player.

b. A better listener.

c. More cooperative with others.

d. More comfortable convincing others.

e. Better at communicating with others.

4) Technical skills in terms of building the expertise to develop a professional web site using different web technologies, and learning from different sources of knowledge and information.

This highly positive student perception is mainly attributed to the use of the PBL approach to implement the leadership model presented in this paper and targeted towards improving students' technical and leadership skills. In fact, $94 \%$ of students were satisfied with the course and its teaching methods, $88 \%$ of students believed that it has improved their conceptual skills, $92 \%$ believed that it improved their management skills, and $89 \%$ of students agreed that the adopted approach improved their interpersonal skills. As part of the survey, students were asked an open ended qualitative question on what was the best thing about this course. The most common features that students liked about the course were: teamwork, experiencing a leadership role in class, the opportunity to define their own real-life project and to be more creative. Examples of answers are as follows:

"The best thing about this course was the ability to develop my personality and become more creative"

"This course is not normal as everybody is part of a group. The work in this course is different. Students decide which project is best for them to do. The teacher in this course pushes students towards creativity"

"Actually, this course is the best that I have seen through my academic life. It gives students a chance to be reliable, confident and more creative"

"The best thing was teamwork. I enjoyed working in groups. I was the leader of my team and I learned how to manage time and communicate with others and how to become a good leader."

"The best thing about this course is that it does not have a lot of lectures. It concentrates more on practice and social skills."

In terms of assessment, students were asked towards the end of the semester to evaluate their peers in terms of teamwork. According to the student survey in appendix A, $78 \%$ of students liked evaluating themselves and their peers, while $15 \%$ were neutral and $4 \%$ of them did not like it.

Although it might seem that using PBL is less demanding for faculty as most of the focus is on student self learning, our experience has proved that it is more demanding for both faculty and students than 
the conventional lecturing approach. In fact, a lot of faculty time is needed to plan the course, design the assessment of the course effectively, select or build appropriate tutorials, provide continuous feedback to students, monitor the progress and contribution of each student within each team, and coach every student through her learning process. A lot of coaching and mentoring has been given to students outside the classroom on conflict resolution and how to communicate with each other. This is a new role that faculty are expected to play, and in general it is not required in the lecturing approach. From students' perspective, $90 \%$ of students felt that this course was more demanding than lecture type courses.

\section{Conclusion}

Technical IT team members require more than technical skills to be effective; they also need leadershiprelated skills (Table 1). Within the limitations of the current IT curricula, it is possible to introduce leadership development in IT courses. The web development course described above fulfills the purpose of integrating the learning of technical and leadership skills in the same course. It allows students not only to learn web technologies and build a professional web site, but also to reflect on and analyze the impacts of their project in the real world. It helps students to learn many management skills like planning, time management, and reporting. Leadership in terms of visioning, teamwork, creativity and communication is also a good feature of the course. We believe, that this course as it is presented, is in line with $A B E T$ current accreditation criteria as well as industry current and future needs.

This course did not include any theoretical aspects of leadership, as this is not its purpose. But leadership development was practiced and occurred from the beginning until the end of the course. Our experience in this course has also shown that giving students the chance to assume greater responsibility for their learning, made them more involved and creative, and therefore it enhanced their learning and personal development.

One limitation of this study is that some of the research cited is based on a Western sample and should be used with caution in non-Western settings. We have not found any extant generalization studies of this Western-based literature. However, Skulmoski and Hartman (2008) examined project manager competencies required for IS projects in the UAE and the required competencies were remarkably similar to the results of a comparable study but with a Western sample (Skulmoski and Hartman, 2009). This should not be surprising because the nature of IS projects varies little as culture varies: for example, the software is the same (e.g. Microsoft), the hardware is the same (e.g. Cisco), the project challenges are the same (e.g. schedule, budget, quality and scope tradeoffs), and the human motivations for project work are the same (e.g. do a good job). As well, the specific competencies seem to apply regardless of where the IS project takes place; for example, at the front end of a project the project manager needs to listen to what is required for project success. He needs the ability to put together a comprehensive and integrated project plan. He needs to be able to help the team solve problems during implementation. During the closeout phase, he needs attention to detail skills to ensure the agreed upon requirements are achieved. Therefore, the competencies that have been identified for successful projects detailed in the Western literature seem logical but could benefit from formal generalization studies.

Future research could include implementing the leadership model presented in this study across the whole curriculum. As development is needed in the four dimensions (technical, interpersonal, conceptual and management), a matrix of IT courses versus leadership development dimensions could be generated to implement and assess development in each dimension across each course of the curriculum. For example, a course on enterprise web development would focus more on conceptual and 
management/business skills than a course on dynamic web programming. In this research, evaluating the success of using PBL to develop leadership skills and teach a technical course was restricted to students' evaluation. While students' feedback and perception are very important in evaluating the suggested approach, we acknowledge that the scale, scope (one course) and time span (two semesters) of this research are very limited. A large scale extended research could involve: i) implementing PBL to develop leadership in all courses of the program, which will take few years ii) following up with students progress in their organizations for many years after graduation, iii) collecting survey data from students' supervisors at work, then iv) drawing more conclusions on students leadership development. The current research was limited to only one course that was tested over two semesters.

\section{Acknowledgment}

This research was funded by a Research Incentive Fund at Zayed University, Dubai. Special thanks to Dr. Anrieta Draganova, Assistant Dean of the College of Information Technology, for administering the survey, collecting and summarizing students' answers.

\section{References}

Abran, A., Moore, J., Bourque, P., Dupuis, R., \& Tripp, L. (2004). Guide to the software engineering body of knowledge. Los Alamitos, USA: IEEE Computer Software.

Abraham, T., Beath, C., Bullen, C., Gallagher, K., Goles, T., Kaiser, K. \& Simon, J. (2006). IT Workforce Trends: Implications for IS programs. Communications of the AIS, 17 (50): 1146-70.

ABET (2008). Criteria for accrediting computing programs. ABET, Baltimore, Md. Accessed 15 October 2008 at <http://www.abet.org/forms.shtml\#For_Computing_Programs_Only>.

Adams, M., Clarke S., \& Thomas R., (2001). Developing Graduate Capabilities Through PBL. Third Asia Pacific Conference on Problem Based learning. December 2001, Rockhampton, Queensland.

Astrachan, O., 2008. CDEF: Interdisciplinary Problem and case based computer science. National Science Foundation Grant no. 0722274. Accessed 15 October 2008 at <http://www.compscipbl.com>.

Bailey, J. and Stefaniak, G. (2001). Industry perceptions of the knowledge, skills, and abilities needed by computer programmers. Proceedings of the 2001 ACM SIGCPR Conference on Computer Personnel Research. San Diego: ACM Press, pp. 93-99.

Barg, M., Fekete, A., Greening, T., Hollands, O., Kay, J., Kingston, J.H. \& Crawford, K. (2000). Problem based learning for foundation computer science courses. Computer science education, 10(2), 109-28.

Barrows, H.S. (1985). How to design a problem-based curriculum for the preclinical years. New York: Springer Publishing Co.

Barrows, H.S. (1986). A taxonomy of problem based learning methods. Medical Education, 20, 481-6.

Barrows, H.S. (1992). The Tutorial Process. Springfield, IL: Southern Illinois University School of Medicine.

Bashein, B., \& Markus, M. L. (1997). A credibility equation for IT specialists. Sloan Management Review, $35-44$.

Bassellier, G., Reich, B., \& Benbasat, I. (2001). Information Technology Competence of Business Managers: A Definition and Research Model. Journal of Management Information Systems, 17(4), 159 182. 
Beaumont, C., \& Frank, B. (2003). Enhancing employability through problem-based learning. Delivering Employability conference. UCLAN, $9^{\text {th }}$ April, 2003.

Beaumont, C., Sackville, A., \& Cheng, C.S. (2004). Identifying Good Practice in the use of PBL to teach computing. ITALICS, 3(1). LTSN-ICS.

Benamati, J., \& Mahaney R.C., (2007). Current and future entry-level IT workforce needs in organizations. ACM-SIGMIS-CPR'07, pp. 101-4.

Benbasat, I., Dexter, A., \& Mantha, R. (1980). Impact of Organizational Maturity on Information System Skill Needs. MIS Quarterly, 4(1), 21 - 34.

Bentley, J. (2002). Introductory Systems Analysis And Design: A Problem-Based Learning Approach. Proceedings of the $13^{\text {th }}$ Australian Conference on Information Systems. Victoria University of Technology, Melbourne, Australia, 4 - 6 December 2002.

Bentley, J. (2005). Simulating Real-Life Problems: Use of Problem-Based Learning in Information Systems. In van Weert, T. \& Tatnall, A. (Eds.) Information and Communication Technologies and Real-Life Learning - New Education for the Knowledge Society. Springer/IFIP, MA, 197-204.

Boud, D., and Feletti, G. (1997). The challenge of problem based learning. $2^{\text {nd }}$ edition. London: Kogan Page.

Bridges, E. \& Hallinger, P. (1996). Problem-based learning in leadership education. In L.Wilkerson and W.Gijselaers (Eds), Bringing problem based learning to higher education: Theory and practice, pp.53-62. San Francisco: Jossey-Bass.

Clarke, S., Thomas, R., \& Adams, M., 2005. Developing case studies to enhance student learning. Proceedings of the $7^{\text {th }}$ Australian conference on computing education. ACM International conference proceedings series, Vol. 106, pp.101-108.

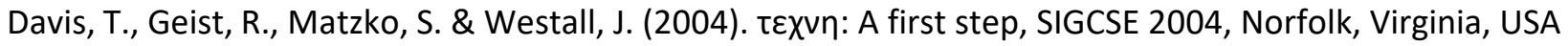

Donner, R.S., Bickley, H., 1993. Problem based learning in American medical education: an overview. Bulletin of the Medical Library Association, 81 (3), 294-8.

Duch, B.J., Groh, S.E \& Allen, D.E. (Eds., 2001). The power of problem based learning: A practical how-tofor teaching undergraduate courses in any discipline. Stylus publishing.

Duke, R., Salzman, E., Burmeister, J., Poon, J. \& Murray, L., (2000). Teaching Programming to Beginners choosing the language is just the first step. ACE 2000,12/00, Melbourne, Australia.

Ellis, A., Carswell, L., Bernat, A., Deveaux, D., Frison, P., Meisalo, V., Meyer J., Nulden, U., Rugelj, J., (1998). Resources, tools, and techniques for problem based learning in computing. In Working group reports of the $3^{\text {rd }}$ annual SIGCSE/SIGCUE ITICSE conference on integrating technology into computer science education. ACM press, pp. 41-56.

Fekete, A. \& Greening T. (1998). Conveying technical content in a curriculum using problem based learning. ACSE' 98 , Brisbane, QLD, Australia.

Garcia-Famoso, M. (2005). Problem based learning: a case study in computer science. Proceedings of the $3^{\text {rd }}$ international conference on multimedia and Information and communication technologies in Education. Accessed 2 February 2008 at <http://www.formatex.org/micte2005/196.pdf>.

Goethals, G., R., \& Sorenson G., L., J. (2006). The quest for a general theory of leadership. Edward Elgar Publishing. 
Greening, T., Kay, J., \& Kingston, J. (1997). Results of a PBL Trial in First-Year Computer Science. In Proceedings of the $2^{\text {nd }}$ Australian conference on computer science education. ACM international conference proceedings, pp. 201-6.

Hadjerrouit, S. (1999). A constructivist approach to object oriented design and programming. In Proceedings of the $4^{\text {th }}$ annual SIGCSE/SIGCSE ITICSE conference on innovation and technology in computer science education. pp. 171-4.

Hämäläinen, W. (2004). Problem based learning of theoretical computer science. Proceedings of the $34^{\text {th }}$ ASEE/IEEE Frontiers in Education Conference. October 20-23, Savannah, GA. pp. 1-6.

Herron, J.F., and Major, C.H., (2004). Community college leaders' attitudes toward problem based learning as a method for teaching leadership. Community College Journal of Research and Practice, 28: 805-21.

House, R.J., Hanges, P.J., javidan, M., Dorfman, P.W., Gupta, V., and Associates (Eds.), 2004. Culture, leadership, and organizations: The GLOBE study of 62 societies. Thousand Oaks, CA: Sage.

Humphrey, W.S. (2006). TSP: Leading a Development Team. Addison Wesley.

Hunter, M. G., \& Beck, J. (1996). A cross-cultural comparison of 'excellent' systems analysts. Information Systems Journal, 6(4), 245-60.

Igbaria, M., \& livari, J. (1995). The Effects of Self-efficacy on Computer Usage. Omega: International Journal of Management Science, 25(6), 587 - 605.

Igbaria, M., Kassicieh, S., \& Silver, M. (1999). Career Orientations and Career Success Among Research, and Development and Engineering Professionals. Journal of Engineering and Technology Management, 16(1), 29 - 54.

Im, I., El Sawy, O., \& Hars, A. (1999). Competence and Impact of Tools for BPR. Information \& Management, 36(6), 301 - 311.

Jiang, J., \& Klein, G. (1998). important behavioral skills for is project managers: the judgments of experienced IS professionals. Project Management Journal, 29(1), 39 - 44.

Jiang, J., Klein, G., \& Means, T. (1999). The missing link between systems analysts' actions and skills. Information Systems Journal, 9(1), 21 - 33.

Katz, R.L. (1955). Skills of an effective administrator. Harvard Business Review, 33(1), 33-42.

Kay, J., Barg, M., Fekete, A., Greening, T., Hollands, O., Kingston, J.H., \& Crawford, K., 2000. Problem based learning for foundation computer science courses. Computer Science Education, 10(2), 109-28.

Kay, D.G., Hoek, A., Richardson, D.J., (2005). Informatics: A focus on Computer Science in Context. ACM SIGCSE Bulletin, 37(1), 551-5.

Kay, J. \& Kummerfeld, B., (1998). A problem based interface design and programming course. SIGCSE 98. Atlanta, GA, USA.

Klein, G., Jiang, J., Shelor, R., \& Balloun, J. (1999). Skill Coverage in Project Teams. Journal of Computer Information Systems, 40(1), 76 - 81.

Klenke, K., (1993). Changing roles of information systems professionals: from technical managers to strategic leaders. Proceedings of the 1993 conference on computer personal research. New York: ACM, pp. 214-225. 
Kumar, S., Hsiao, J.K., (2007). Engineers learn soft skills the hard way: planting a seed of leadership in engineering classes. Leadership and Management in Engineering, 7(1), 18-23.

Lambrix, P., and Kambar, M., (1998). Computer Science as an integrated part of engineering education. In Proceedings of the $6^{\text {th }}$ annual conference on the teaching of computing and the $3^{\text {rd }}$ annual conference on integrating technology into computer science education. ACM press, pp. 153-6.

Lee, D.M.S., Trauth, E.M., Farwell, D. (1995). Critical skills and knowledge requirements of IS professionals: A joint academic/industry investigation. MIS Quarterly, 19(3): 313-40.

Lerouge, C., Newton, S., \& Blanton, J. E. (2005). Exploring the Systems Analyst Skill Set: Perceptions, Preferences, Age, and Gender. The Journal of Computer Information Systems, 45(3), 12-24.

Major, C.H. (1999). Connecting what we know and what we do through learning. AAHE Bulletin 51(7), 79.

Major, C.H. (2001). Assessing problem-based learning: a review and analysis of faculty developed PBL course portfolios. Journal on Excellence in College Teaching 11(2-3), 113-32.

Marcolin, B., Compeau, D., Munro, M., \& Huff, S. (2000). Assessing user competence: conceptualization and measurement. Information Systems Research, 11(1), 37 - 60.

Marcolin, B., Munro, M., \& Campbell, K. (1997). End user ability: impact of job and individual differences. Journal of End User Computing, 9(3), 3-12.

Marti, E., Gil, D. \& Julia, C. (2006). A PBL experience in the teaching of computer graphics. Computer Graphics Forum, 25(1), 95-103.

McCracken, M. \& Waters, R. (1999). WHY? When an otherwise successful intervention fails. In Proceedings of the fourth ITiCSE conference. ACM SIGCSE Bulletin, 31(3), 9-12.

Mendonca, J. (2004). Organizational impact of Information technology: A leadership course for IT. Proceedings of the fifth conference on information technology education, SIGITE'04. Utah: ACM, pp. 2447.

Morneau, K.A., and Talley, S., 2007. Architecture: An emerging core competence for IT professionals. ACM Special Interest Group for Information Technology Education, SIGITE '07. Florida, USA.

Mumford, M.D., Zaccaro, S.J., Connelly, M.S., \& Marks, M.A. (2000a). Leadership skills: Conclusions and future directions. Leadership Quarterly, 11(1), 155-170.

Mumford, M.D., Zaccaro, S.J., Harding, F.D., Jacobs, T.O., \& Fleishman, E.A. (2000b). Leadership skills for a changing world: Solving complex social problems. Leadership Quarterly, 11(1), 11-35.

Mumford, T.V., Campion, M.A., \& Frederick P.M. (2007). The leadership skills strataplex: Leadership skill requirements across organizational levels. Leadership Quarterly, 18(2), 154-66.

Munro, M., Huff, S., Marcolin, B., \& Compeau, D. (1997). Understanding and measuring user competence. Information \& Management, 33(1), 45 - 57.

Nord, G. D., \& Nord, J. (1995). Knowledge and Skill Requirements Important for Success as a Systems Analyst. Journal of Information Technology Management, 6(3), 47 - 52.

Nuutila, E., Törmä, S., \& Malmi, L. (2005). PBL and computer programming - the seven steps method with adaptations. Computer science education, 15(2), 123-42. 
O'Connor, B.N. (2004). The workplace learning cycle: a problem-based curriculum model for the preparation of workplace learning professionals. Journal of workplace learning, 16(6): 341-9.

O'Kelly, J., Monahan, R., Gibson, J.P. \& Brown, S. (2005). Enhancing skills transfer through problem based learning. Technical report series: NUI-CS-TR-2005-13, Department of Computer Science, National University of Ireland, Maynooth, Ireland.

O'Kelly, J., \& Gibson, J.P., (2006). RoboCode and problem-based learning: A non-prescriptive approach to teaching programming. Proceedings of the $11^{\text {th }}$ annual ACM SIGCSE conference on innovation and technology in computer science education. ITiCSE 2006, Bologna, Italy.

Oriogun, P.K. \& Georgiadou, E. (2000). Towards ensuring the development of capabilities through the use of the problem based learning grid. $8^{\text {th }}$ Annual conference on the teaching of computing. Edinburgh.

Pollock, L., \& Jochen, M. (2001). Making parallel programming accessible to inexperienced programmers through cooperative learning. SIGCSE 2001, 2/01, Charlotte, NC, USA.

Prince, M., (2004). Does active learning work? A review of the research. Journal of Engineering Education, 93(3), 223-31.

Reich, B.H., \& Nelson K.M. (2003). "In their own words: ClO visions about the future of in-house IT organizations". The DATA BASE for advances in information systems, 34(4): 28-44.

Savery J.R. (2006). Overview of problem based learning: definitions and distinctions. Interdisciplinary Journal of Problem-based Learning, 1(1): 9-20.

Schmidt, H. and Moust, J. (2000). Factors affecting small-group tutorial learning: a review of research. In D. Evensen and C. Hmelo (Eds), Problem based learning. (pp. 19-52). Mahwah, NJ: Lawrence Erlbaum.

Seppanen, V. (2002). Evolution of competence in software contracting projects. International Journal of Project Management, 20, 155 - 164.

Segers, M. \& Dochy, F. (2001). New assessment forms in problem-based learning: the value-added of the student's perspective. Studies in Higher Education, 26(3), 327-43.

Segers, M., Dochy, F., \& de Corte E. (1999). Assessment practices and students' knowledge profiles in a problem-based curriculum. Learning Environments Research 2(2), 191-213.

Skulmoski, G. \& Hartman, F. (2008). The competent project manager: the soft competencies required for successful IS projects. International Association for Management of Technology: Creating and Managing a Knowledge Economy. Dubai, UAE, April 6-10, 2008.

Skulmoski, G. \& Hartman, F. (2009). The Progression Towards Project Management Competence. Handbook of Research on Technology Project Management, Planning, and Operations. Information Science Reference.

Todd, P., Mckeen, J., \& Gallupe, R. B. (1995). The Evolution of IS Job Skills: A Content Analysis of IS Job Advertisements From 1970 to 1990. MIS Quarterly, 19(1), 1 - 27.

Trauth, E.M. and Hafner, C. (2000). Meeting the IT skills crisis: an interdisciplinary response. Proceedings of the Americas Conference on Information Systems. Long Beach, California, pp. 1946-51.

Tye, E., Poon, R., and Burn, J.M. (1995). Information systems skills: achieving alignment between the curriculum and the needs of the IS professionals in the future. The database for advances in information systems, 26(4): 47-61.

Lahkim, M., Skulmoski, G.J. \& Bruhn, R.E. (2009). Improving IT education through leadership development. Learning and teaching in higher education: Gulf perspectives, 6(1). http://www.zu.ac.ae/Ithe/Ithe06_01_03_lahkim 
Uden, L. (2003). Problem-Based Task Knowledge Structures in Projects. In O'Reilly, U. (Ed.) $4^{\text {th }}$ Annual Conference of the LTNS Centre for Information and Computer Science. NUI Galway, Ireland, 25-28 August, 2003. pp. 97-102.

Uden, L., \& Beaumont, C. (2006). Technology and problem based learning. Information science publishing.

Waters, R. \& McCracken, M. (1997). Assessment and evaluation in problem-based learning. IEEE Frontiers in Education Conference.

Yammarino, F.J. (2000). Leadership skills: introduction and overview. Leadership Quarterly, 11(1), 11-35.

Yeo, R.K., 2007. Problem-based learning: a viable approach in leadership development. Journal of management development, 26(9): 874-94.

Yip, W., \& Ghafarian, A. (2000). Problem based learning assessment for information systems courses. Proceedings of the $15^{\text {th }}$ annual conference of the International Academy for Information Management. Brisbane, Australia.

Zwieg, P., Beath, C.M., Bullen, C.V., Gallagher, K.P., Goles, T., Howland, J., Simon, J.C., Abbott, P., Abraham. T., Carmel, E. Evaristo, R., Hawk S., Lacity, M., Gallivan, M., Kelly, S., Mooney, J.G., Ranganathan, C., Rottman, J.W., Ryan, R. \& Wion, R. (2006). The Information Technology Workforce: Trends and Implications 2005-2008. MIS Quarterly Executive, 5(2): 47-54.

\section{Authors}

Dr. Mohammed Bennani Lahkim earned his PhD in engineering from Colorado State University in 1998 on a Fulbright scholarship. He is currently an Assistant Professor at the College of Information Technology, Zayed University, UAE. His current research interest are in web technologies and creating new curricula involving leadership development.

Dr. Greg J. Skulmoski joined the College of Information Technology at Zayed University in 2002, and he teaches project management there. His research is in team member competence, project selection and risk management. Greg has extensive PMI standards development expertise and is one of the authors of the $2000 \mathrm{PMBOK}^{\circledR}$ Guide.

Dr. Russel Bruhn earned his PhD in Electrical Engineering from Washington State University in 1997. He is an Associate Professor and Associate Dean at Donaghey College of Engineering and Information Technology, University of Arkansas at Little Rock, U.S. Dr. Bruhn has held many management positions in the U.S. and the UAE in the areas of computer science and information systems. 


\section{Appendix A:}

CIT 245: Web development, Zayed University, Dubai, UAE.

Date: 09/06/ 2008

No. of responses $=52$

\begin{tabular}{|c|c|c|c|c|c|c|}
\hline After taking this course, & $\begin{array}{l}\text { Strongly } \\
\text { agree }\end{array}$ & Agree & Neutral & Disagree & $\begin{array}{l}\text { Strongly } \\
\text { disagree }\end{array}$ & N/A \\
\hline & 5 & 4 & 3 & 2 & 1 & 0 \\
\hline \multicolumn{7}{|l|}{ Conceptual skills } \\
\hline 1. I have become a better leader/follower & $42 \%$ & $46 \%$ & $10 \%$ & $0 \%$ & $0 \%$ & $2 \%$ \\
\hline 2. I have become a more independent learner & $46 \%$ & $48 \%$ & $6 \%$ & $0 \%$ & $0 \%$ & $0 \%$ \\
\hline 3. I feel that I had a chance to be more creative & $73 \%$ & $17 \%$ & $6 \%$ & $2 \%$ & $2 \%$ & $0 \%$ \\
\hline 4. I feel more confident about my abilities & $54 \%$ & $31 \%$ & $8 \%$ & $0 \%$ & $0 \%$ & $8 \%$ \\
\hline 5. I am better at problem solving & $42 \%$ & $38 \%$ & $15 \%$ & $4 \%$ & $0 \%$ & $0 \%$ \\
\hline Summary on conceptual skills & $52 \%$ & $36 \%$ & $9 \%$ & $1 \%$ & $0 \%$ & $2 \%$ \\
\hline \multicolumn{7}{|l|}{ Management/ Business skills } \\
\hline 1. I have become better at planning my work & $69 \%$ & $27 \%$ & $4 \%$ & $0 \%$ & $0 \%$ & $0 \%$ \\
\hline 2. I have become better in time management & $52 \%$ & $35 \%$ & $8 \%$ & $4 \%$ & $0 \%$ & $2 \%$ \\
\hline Summary on management skills & $61 \%$ & $31 \%$ & $6 \%$ & $2 \%$ & $0 \%$ & $1 \%$ \\
\hline \multicolumn{7}{|l|}{ Interpersonal skills } \\
\hline 1. I have become a better at teamwork & $56 \%$ & $35 \%$ & $8 \%$ & $0 \%$ & $0 \%$ & $2 \%$ \\
\hline 2. I have become better at listening to others & $67 \%$ & $29 \%$ & $4 \%$ & $0 \%$ & $0 \%$ & $0 \%$ \\
\hline $\begin{array}{l}\text { 3. I feel more comfortable sharing information } \\
\text { and cooperating with others }\end{array}$ & $62 \%$ & $29 \%$ & $10 \%$ & $0 \%$ & $0 \%$ & $0 \%$ \\
\hline $\begin{array}{l}\text { 4. I feel more comfortable influencing and } \\
\text { convincing others }\end{array}$ & $44 \%$ & $29 \%$ & $27 \%$ & $0 \%$ & $0 \%$ & $0 \%$ \\
\hline $\begin{array}{l}\text { 5. I improved my abilities to communicate with } \\
\text { others }\end{array}$ & $65 \%$ & $29 \%$ & $6 \%$ & $0 \%$ & $0 \%$ & $0 \%$ \\
\hline Summary on interpersonal skills & $59 \%$ & $30 \%$ & $11 \%$ & $0 \%$ & $0 \%$ & $0 \%$ \\
\hline \multicolumn{7}{|l|}{ Technical Skills } \\
\hline $\begin{array}{l}\text { 1. I feel more comfortable learning from } \\
\text { different sources of knowledge \& information }\end{array}$ & $58 \%$ & $38 \%$ & $2 \%$ & $2 \%$ & $0 \%$ & $0 \%$ \\
\hline $\begin{array}{l}\text { 2. I feel more confident in developing a } \\
\text { professional web site, and using different web } \\
\text { technologies }\end{array}$ & $46 \%$ & $44 \%$ & $10 \%$ & $0 \%$ & $0 \%$ & $0 \%$ \\
\hline
\end{tabular}




\begin{tabular}{|l|l|l|l|l|l|l|} 
Summary on technical skills & $52 \%$ & $41 \%$ & $6 \%$ & $1 \%$ & $0 \%$ & $0 \%$ \\
\hline General aspects of the course & & & & & & \\
\hline $\begin{array}{l}\text { 1. I liked evaluating myself and other team } \\
\text { members }\end{array}$ & $40 \%$ & $38 \%$ & $15 \%$ & $4 \%$ & $0 \%$ & $2 \%$ \\
\hline $\begin{array}{l}\text { 2. I feel this course is more demanding than a } \\
\text { normal lecture type course }\end{array}$ & $71 \%$ & $19 \%$ & $4 \%$ & $6 \%$ & $0 \%$ & $0 \%$ \\
\hline 3. I am satisfied with the overall course & $73 \%$ & $21 \%$ & $4 \%$ & $2 \%$ & $0 \%$ & $0 \%$ \\
\hline Summary on overall course evaluation & $62 \%$ & $26 \%$ & $8 \%$ & $4 \%$ & $0 \%$ & $1 \%$ \\
\hline Profile across all questions & $57 \%$ & $33 \%$ & $8 \%$ & $1 \%$ & $0 \%$ & $1 \%$ \\
\hline
\end{tabular}

